\title{
British Thermal Unit Thermochemical
}

National Cancer Institute

\section{Source}

National Cancer Institute. British Thermal Unit Thermochemical. NCI Thesaurus. Code C69155.

A non-SI unit of energy equal to the amount of heat required to raise the temperature of one pound avoirdupois of air-free water by one degree Fahrenheit at a constant pressure of one atmosphere, based on the definition of the thermochemical calorie (exactly 4.1840 joules) by the U.S. Bureau of Standards, 1953. The thermochemical British thermal unit is equal to approximately $1.05435026444 \mathrm{~kJ}$. 